\title{
Indo-Pak Relations: New Trends and Challenges
}

\author{
Sanjeet Kumar
}

\begin{abstract}
British India was divided into India and Pakistan in 1947 as a part of the decolonization process. But geographically, historically and culturally no other two states have so much common as these two states. Unfortunately both stats never became good friends and always engaged in conflicts and disputes. The greatest tragedy was that the deciding feature of this division was religion. Today, more than sixty five years after independence, the common people as well as the elite of India and Pakistan are concerning towards establishing condition for permanent peace. It is no secret now that India and Pakistan are nuclear capable powers. So, it is in India's interest that democracy succeeds in Pakistan so that the dividend of 'Democratic Peace' can be harvested in South Asia. Because improving relations of both the nations is very important for sustaining peace in South Asia. Yet, the Indian Strategy has not been able to translate the intent into reality. The aim of this paper is to know about the new trends, challenges and future prospects for sustaining peace. Despite all this, it was convinced that we were on the wrong track as far as neighborhood management was concerned. We needed a new approach to convert the traditional confrontation and conflict approach to one of cooperation and convergence. If there is cooperation between India and Pakistan and not conflict, vast opportunities will open up for trade, travel and development that will create prosperity in both nations.
\end{abstract}

Key Words: Decolonization, Democratic Peace.

\section{Introduction}

British India was divided into India and Pakistan in 1947 as a part of the decolonization process. The eastern wing of Pakistan emerged as the new nation called Bangladesh in 1971. It was not first time that the world had witnessed the creation of new nation states and boundaries by the victors of wars or imperial forces. The creation of Lebanon, Northern Ireland, Israel and various nations in Africa are example of this strategy. But geographically, historically and culturally no other two states have so much common as these two states. But it is strange that despite these similarity relations between these two states not so much smooth and peaceful. Roots of this kind of relationship between India-Pakistan can be seen in the colonial history of Indian subcontinent. British colonial rules established a tradition by the partition of this subcontinent that creates a chain of struggles, disputes and instability in the region.

Unfortunately India and Pakistan never became good friends and always engaged in conflicts and disputes. There is a fair amount of scholarly agreement that partition occurred not because of Hindus and Muslim could not live together, but because the elite of the two communities could not agree to power sharing. The greatest tragedy was that the deciding feature of this division was religion. Today, more than sixty five years after independence, the common people as well as the elite of India and Pakistan are concerning towards establishing condition for permanent peace. But unfortunately the situation is not so much better for India and Pakistan which it should be but the power of the old mindset is declining and the momentum for peace is growing.

\section{New Trends}

Now the world entered in the twenty first century. In this century relations between two countries represent policies of two countries. Nations does not exist in vacuum, they exist in a particular environment and have to adopt it, like any other organism. The making of foreign policy depends on various issues such as external threat, geographical location, strategic significance political aspirations, economic requirements, ideology, and personality of the statesmen and over all national interests. But in this century the people of the two countries are at the heart of the relationship. The following issues can be trace for analyzed the new trends between India and Pakistan.

\section{Role of Military}

It is well documented that in contrast to India, Pakistan started its journey as an independent state without the political infrastructure around which democracy could grow and develop. This institutional deficit created the space for the early rise of the military as an autonomous and powerful actor in domestic politics in Pakistan. ${ }^{1}$ Therefore the Pakistani military, especially the army, has a very special place in the Pakistani

${ }^{1}$ Aquil Shah, "Security, Soldiers, and the State in Pakistan", Seminar, 611, July, 2010,p.23. 
hierarchy and politics. According to Stephen Cohen "The military is only one component of the wider establishment that runes Pakistan." According to a humorless Pakistani joke "All countries have armies, but here an army has a country". On the other hand the Indian army also occupies a dominating position vis-à-vis the other two services. The Indian armed forces have never interfered with politics. In India, civil authority is supreme. Indian armed forces, are a voluntary forces provide the much needed stability and strength to the Indian democratic system, and have played major role in maintaining peace and security all over this troubled world under the aegis of the United Nations.

It is commonly accepted that the Pakistani Military's hard-line stance towards India is at the root of strained relations between India and Pakistan. In view of this the argument goes there is little to gain from engaging the Pakistani military. If the military are in power, then peace process disturbs. It is in India's interest that democracy succeeds in Pakistan so that the dividend of 'democratic peace' can be harvested in South Asia. Because improving relations with Pakistan is in Indian interests. India is very much alive to this and has made considerable efforts in this direction and wanting a stable neighbor at peace with itself. Yet, the Indian Strategy has not been able to translate the intent into reality. ${ }^{2}$

\section{Nuclear Issue}

Nuclear weapons have transformed military power into a very expensive and dangerous tool of statecraft. It should not be exercised without a great deal of wisdom. It is no secret now that India and Pakistan are nuclear capable powers and have bombs. Pakistan, however, bases its nuclear option only on its threat perception from India which is far superior to Pakistan in terms of conventional forces. Therefore Pakistan argues, its security can be safeguarded only through nuclear deterrence. Pakistan's nuclear and missile programmes are part of its strategy to internationalize the Kashmir issue using the threat of an Indo-Pak nuclear war, to achieve parity with India in Military terms, and in International strategic and security perception, to ensure UN intervention in bilateral issue and defense policies of India. This again poses a threat to India's security. Further, china's growing nuclear and missile collaboration with Pakistan adds a worrying dimension for India. ${ }^{3}$ Pakistan got permission in March 2011 from IAEA(International Atomic Energy Agency) to establish two nuclear reactor with the help of $\mathrm{China}^{4}$ is also poses threat before India.

\section{Role of Judiciary}

Judiciary now a day's becomes as dominant institution over the legislature and executive in Pakistan. This is unfortunate for the democratic system of Pakistan that in the past it is dominated by the military and in present it is by the judiciary. The removal of the prime minister of Pakistan by its Supreme Court is the latest round of long struggle between the elected and unelected parts of the Pakistan state. However this time it is not the military but rather the judiciary which is directly confronting the democratically elected government, with the supports of the media and other political parties. This has changed the terrain of the conflict which cannot be defined in traditional terms anymore. ${ }^{5}$ But on the other hand Judiciary works as an important pillar of democratic system in India rather than as a dominating institution over the legislature and executive. This strengthen the democracy in India so it will be beneficial for both the states that the judiciary should works as an pillar of democratic system in Pakistan to strengthen democracy there.

\section{Cultural Issues}

The Social and cultural relationship with Pakistan is also an area which matters to concerns the emotions and belief of a common man. Minorities of the both nations like Hindus in Pakistan and Muslims in India are still not mingled up and attached with the society in which they live.

However being a large number like 170 million Muslims in India enjoy an equal right to cast their vote and have to come counted. They influence elections in Lok Shabh and the backward among them have been able to get reservation like Other Backward Classes(OBCs). But the problem of Hindus in Pakistan, said to be some 7 million, is that they are not large enough to have any say in political matters, nor are they content with they have been reduced to after partition ${ }^{6}$. But the religion of two Hindu girls and a Boy changed in August 2012 and forcefully married them with Muslims by some extremists group and there was a live telecast of this incidentalso but there was no steps taken by the Pakistan governments. This kind of situation creates gap and distance in efforts of establishing stable peace in the region.

\footnotetext{
${ }^{2}$ Ali Ahmed, "India-Pakistan Relations: Military Diplomacy Vs Strategic Engagement", Journal of Defence Studies and Analyses, vol.5, no.1, January,2011.

${ }^{3}$ Poonam Mann, India's Foreign Policy in the Post Cold War Era, Harman Publishing, New Delhi, 2000, pp.108110.

${ }^{4}$ The Statesman, 15 April, 2011.

${ }^{5}$ Mohammad Waseem, "Clash of Institutions in Pakistan", cited in EPW, Vol. XLVII, no.28, July 14, 2012, p.16.

${ }^{6}$ The Tribune, 23 August, 2012.
} 


\section{Challenges}

India and Pakistan have now passed the stage of serious tension for them to be discussing such innovative proposals, and their relations although far from normal. But still areas like terrorism, humanitarian issues, peace and security, including confidence building measures, Jammu and Kashmir, Promotion of friendly exchanges, Siachen, economic issues and the Wullar Barage/Tulbul Navigation Project and the issue of Sir-Creek and now a day's issue of Afghanistan also are major challenges. Both India and Pakistan have yet to move forward in certain difficult security areas, facilitate easier visa regimes, improve economic relations and ease tough posturing over Kashmir. Moreover, unlike the past, the current process of composite dialogue has survived the government changes in the two countries, reflecting an expanding consensus across the borders to move the peace process ahead.

Indo-Pakistan engagement has taken place in multiple phases. In the first phase, from 1947, to the mid 1980 's, the two governments were the principle actors, they talked for peace but remained ever ready for war, and, indeed, actively clashed four times. In the second phase, from mid 1980's to mid 1990's, sections of the intelligentsia in both India and Pakistan start working for peace. In the third phase people of India became active. They voted for peace for their feet. In the process, they built such immense pressure on the two governments as to leave them little option but to establish and then go forward with the process of peace. ${ }^{7}$ Numerous groups have been engaged in promoting Indo-Pak friendship. Some of these groups are:

Pakistan-India People's forum for Peace \& Democracy(PIPFPD), Association of Peoples of Asia(APA), Women in Security conflict Management and Peace(WISCOMP), South Asian Forum of Human Rights(SAFHR), Pakistan Peace Coalition and the coalition for Nuclear Disarmament and Peace(CNDP) and India Pakistan Soldiers Initiative for Peace(IPSI).

After having engaged each other in conflicts in 1947, 1965, 1971 and 1999, there has been gradual recognition by both New Delhi and Islamabad that unless remedial measure were taken, relations would reach no-return. However, with the coming in of the BJP government in 1998, and the nuclear tests by both states give status of nuclear power to these. The period between 1999 and 2002 witnessed a high level of tension between India and Pakistan due to number of factors, including among others, the Kargil crisis(May-July 1999), the inconclusive Agra Summit(July 2001), the attack on the Indian Parliament(December 2001) and the mobilizing of a million troops on the border, which was called off by India. After Kargil conflict and attacks on J\&K legislative assembly and Indian Parliament in 2001 there was tensions on border across LOC and the ceasefire declared. The Prime Minister of India Atal Bihari Vajpayee extending "the hand of friendship" towards Pakistan. Pakistan responded large number of CBMs including announcement of the ceasefire on the LOC. ${ }^{8}$

Foreign Secretary Nirupama Rao and her Pakistani counterpart Salman Bashir in Thimphu on the sidelines of a South Asian Association for Regional Cooperation(SAARC) meeting and agreed to hold talks on eight subject which are counter-terrorism, humanitarian issues, peace and security, including confidence building measures, Jammu and Kashmir, Promotion of friendly exchanges, Siachen, economic issues and the Wullar Barage/Tulbul Navigation Project and the issue of Sir-Creek. Ms. Rao had hinted at the talks incorporating a new subject Afghanistan. She also came up with new ideas and said that "why should we be just struk with discussing these issues, why cannot we discuss more issues? Why cannot we discuss the situation in our region?"

Pakistan has at realized that it will be a gained by according the most favored nation status to India in matters of trade and commerce. India took such a decision in the case of Pakistan a few years back. This has given strength to the argument advanced by some influential people in Pakistan like Maulana Fazulur Rehman that "Islamabad's attitude towards India must soften in view of the changing regional and global reality. Two, Pakistan's community has made a strong recommendation for MFN status to India, saying that it changed scenario. ${ }^{10}$

CBM's regarding strategic issues are aimed to strengthen the relations. Consequently, both states agreed to engage in bilateral consultations on security concepts and nuclear doctrine. Advance notification in respect of ballistic missiles flight test. Review of existing communication links and engage in bilateral consultations on security disarmament. Both states agree to upgraded, dedicated and secure hotlines at three levels, political, executive and military. By these lines Prime Ministers, Foreign Secretaries and Director General of Military operations of both states connected. Besides, during different meetings both continue to add

\footnotetext{
${ }^{7}$ Mubashir Hasan, "The Pakistan-India Peace Process", cited in Simtu Kothari, Zia Man(eds.) and et.al, Bridging Partition People's Initiatives for Peace between India and Pakistan, Orient Blackswan, New Delhi, 2010, pp. 1920.

${ }^{8}$ The Times of India, February 17, 2011.

${ }^{9}$ The Hindu, February 11, 2011.

${ }^{10}$ The Tribune, October 5, 2011.
} 
some new proposals related to strategic CBM's for Instance, Natwar singh added a proposal to shared nuclear doctrine between India-Pakistan and China. Similarly Pakistani side added twenty new proposals, including 'the elements of a strategic regime. ${ }^{11}$

Indian foreign Minister S M Krishna and his Pakistani counterpart Hina Rabbani Khar announced new Confidence Building Measures (CBMs) and expected that these will expand the scope of people to people contacts and humanitarian issues. The CBMs include increasing cross-LOC trading days and expanding travel to include tourism and religious aspects, apart from relaxing permit conditions for travel by people of Jammu and Kashmir to the other side of LOC by having a system of Six month multiple entry, To move forward and forge a cooperative relationship though they stuck to their known positions on key issues such as Kashmir and terror. ${ }^{12}$

\section{Future prospects}

There is no doubt that people on both sides want contact, not distance. According to Kuldip Nayar "When the border was thrown open for the for a day after the eight and nine years of independence. It was for hockey match between India and Pakistan at Lahore. No passport was required. People from India had to show some identification papers. Every Indian had very warmth welcome from their side that touched everybody's heart. It looked as if separated friends had met. Every restaurants and eating shops did not charge money from Indians. Tongas, rickshaws and taxis carried them free." In the same way we started lightning candles at Wagah border after forty ninth year of independence. After lighting candles at midnight right at the gate on border, the official ceremony is over. But people continue to stay there till the early hours of the morning. In 2006, the year of writing, it had to be seen to be believed. A huge number of people gathered at the same border nearly 500,000 poople had only one slogan on their lips: 'Hindustan Pakistan dosti zindabad' (long live India-Pakistan friendship') ${ }^{13}$. This shows that people of both states want always live together, then why government of both states cannot engaged for permanent peace of the subcontinent.

There were quite a few reasons at this time which gave confidence to the governments to embark on a new peace process. Both countries had tried everything including war and mobilization of troops to force the other to accept its version of Kashmir Settlement. They failed in this. Secondly, nuclear parity in South Asia made war almost impossible. Thirdly, The economies of both the countries were doing very well at this time and the rising middle classes in both countries desired peace for continued growth.

US think-tank has proposed a dialogue between India and The Pakistan Army. The proposal has merit to the extent that the army is a stark reality in Pakistan's policy. Because General Zia-ul-Haq once said that "It would be better off in settling Kashmir and other matters with the army because if and when democracy returned to Pakistan India would have problem. It is true that New Delhi has not reached anywhere with the "democratic" government in Islamabad. But it is equally true that army never left Pakistan alone. There is no movement on any issue, reportedly because of the army's disinterest. ${ }^{14}$

This necessitated an alternative strategy for a solution of the Kashmir dispute which would satisfy the people of Kashmir, India, Pakistan. That being the case, it was clear that any solution we found would not be an ideal one from the perspective of all Kashmiri's, Pakistani's, and Indians. It could only be the best under the circumstances. The major features of draft Kashmir agreement involved a gradual demilitarization as the situation improved, self governance and a joint mechanism involving Kashmiris from both sides as well as the presence of Pakistani and Indian representatives in some from other. The purpose was to improve the comfort level of Kashmiris. ${ }^{15}$

The naval authorities on both sides have also establish a hotline mainly to avoid arresting fishermen from either side who stray accidentally into each other's waters, and which has considerably reduced arrests on both sides. The coast guard authorities on both sides are now debating the possibility of holding joint search and rescue operations and collaborating in marine pollution control. ${ }^{16}$

The positive steps from the two sides has couched the reluctance of Pakistan to move forward on range of conventional military CBM's that would called for structured interaction and communication between two military establishments. ${ }^{17}$

\footnotetext{
${ }^{11}$ R.S. Yadav, "India-Pakistan Peace process: A Study of CBM's”, South Asian Studies, vol.43, no.1, January-

December, 2008, pp.89-90.

${ }^{12}$ The Indian Express, July 28, 2011.

${ }^{13}$ Kuldip Nayar "People to People Contact" op. cit, no.4,pp.88-89.

14 The Tribune, October $10,2011$.

${ }^{15}$ The Times of India, February 17, 2011.

${ }^{16}$ Samarjit Ghosh, “India-Pakistan Relations: Composite Dialogue in Stasis” in D. Suba Chandran and Jabin T. Jacob(eds.), India's Foreign Policy Old Problems, New Challenges, MacMillan, Delhi, 2011.

${ }^{17}$ C Raja Mohan, "Ten Question on peace process", EPW, July 10, 2004, p. 3097.
} 
One would think that exchange of intelligence information among friendly agencies was occurring as a matter of course to help fill information gaps, to verify of sources and substance, and to get a 'second opinion'. However, as any report on intelligence reform or failures shows, the absence of coordination, even among their own agencies remains problematic. When countries are faced with common external or internal threats, exchange of mutually beneficial information might not only be thinkable but also desirable, even prudent. Even in the worst days of Cold War, the CIA and KGB never ceased contacts, even through open declared officers in each other's capitals. Intelligence links between neighbours are obviously desirable. It is better to institutionalize them now, rather than trying to activate them in times of crisis.Intelligence links can succeed where all others fail. What agencies can achieve is not at times even conceivable in political or diplomatic channels. As the two sides develop trust and rapport, the canvass is bound to expend. One day even trials might become possible. ${ }^{18}$

It may strange and perhaps even unbelievable that as late as 1962, the India and Pakistan Navy used to exercise together under the banner of joint exercise held at and off Tricomalee(SriLanka), Known as JET for short. These exercises were conducted annually by the British as a part of the commonwealth Navel exercises. Other Navies that took part were form Australia, Canada, Sri Lanka, and, of course, the Royal Navy from UK. Alas, all this came to an end after 1965 war of India-Pakistan.In 1992 India held a very successful International seminar under the aegis of the Navy Foundation, titled "Challenges and opportunities in the Indian Ocean for the next century." The ships of both India and Pakistan worked tighter to render help after Tsunami waves hit Maldives.The two armies had worked under the under the United Nation command during peace keeping operations in Somalia, Congo and elsewhere. There is no reason why this kind of synergy cannot be extended in the future to work towards regional security. ${ }^{19}$

\section{Conclusion}

Wars did not resolve any issue in the past. We believe that Kashmir can well become the bridge to peace between the two countries, which has so far been the primary cause of hostility between India and Pakistan. The collaboration of civil and military spheres for peace gained legitimacy, needless to say this kind of synergy is only the beginning and needs to be consolidated and further strengthened through a combination of initiatives in the years ahead. Despite all this It was convinced that we were on the wrong track as far as neighborhood management was concerned. We needed a new approach to convert the traditional confrontation and conflict approach to one of cooperation and convergence. People in South Asia, home to a vast majority of the world's poor, need the availability of employment opportunities more than anything else. This is essential so that no one takes interest in destructive activities like terrorism. If there is cooperation between India and Pakistan and not conflict, vast opportunities will open up for trade, travel and development that will create prosperity in both nations.

\footnotetext{
${ }^{18}$ The Hindu, July 14, 2011.

${ }^{19}$ Laxminarayan Ramdas, "Sustaining India-Pakistan Peace: Challenges for Civil society and Military." op. cit., no.4.
} 